\title{
Knowledge Regarding Prevention of Mother to Child Transmission of HIV/AIDS among Antenatal Mothers in Nepal
}

\author{
Radha Acharya, ${ }^{1,2 \dagger}$ Trishna Acharya, ${ }^{3,4}$ Ramesh Devkota $^{4}$ \\ ${ }^{1}$ Department of Nursing, Hope International College, Purbanchal University, Satdobato, Lalitpur, Nepal, ${ }^{2}$ Bir \\ Hospital, Kathmandu, Nepal, ${ }^{3}$ Nepal Health Research Council, Ramshah Path, Kathmandu, Nepal, \\ ${ }^{4}$ Department of Pharmacy, National Model College for Advance Learning, Tribhuvan University, \\ Kathmandu, Nepal, \\ ${ }^{\dagger}$ Equal contributors
}

\section{Correspondence}

Ms. Trishna Acharya,

Nepal Health Research Council,

Ramshah Path, Kathmandu

Email:

shna.tris@gmail.com

DOI: http://dx.doi.org/10.3126/ jemsn.v14i1.18761

Orcid ID: orcid.org/0000-0003 $-4982-0205$

Article received: Dec $21^{\text {st }} 2017$ Article accepted: Mar $24^{\text {th }} 2018$

\begin{abstract}
Background \& Objectives: Prevention of Mother to child Transmission (PMTCT) is a global intervention which aims at preventing mother to child transmission of Human Immunodeficiency Virus (HIV). The study aims to find out knowledge of pregnant women on Mother to child Transmission (MTCT) of HIV/AIDS (Acquired Immune Deficiency Syndrome). Materials \& Methods: A cross-sectional study was carried out at Paropakar Maternity and Women's Hospital, Kathmandu, Nepal among the pregnant women who came to visit Antenatal Clinic. Data was collected using non-probability purposive sampling technique. Face to face interview was done and a structured questionnaire was developed for data collection. Data analysis and interpretation were done in SPSS and MS Excel. Results: The total number of respondents was 80 with a mean age of 27.4 years. $90 \%(n=72)$ respondents were found to be literate. $86.3 \%(\mathrm{n}=69)$ were well aware of the knowledge on PMTCT. Majority of the respondents $(40 \%)$ mentioned that radio, TV/Media were the main sources of information about HIV/AIDS. Out of 32.5\% (26) who had heard about the window period, only $26.9 \% \quad(n=7)$ gave the correct answer. $93.8 \%(\mathrm{n}=75)$ were well known about the routes of transmission of HIV but only $10.1 \%(n=7)$ gave the correct answer about it. Further, $54 \%(n=43)$ respondents knew about the availability of drugs to reduce MTCT of HIV/AIDS. Conclusion: The level of awareness about PMTCT among antenatal mothers was satisfactory. However, knowledge was inadequate which imparts for the need of health education about MTCT of HIV/AIDS in every health facilities of Nepal.
\end{abstract}

Key words: Antenatal mothers; HIV/AIDS; Knowledge

Citation: Acharya R, Acharya T, Devkota R. Knowledge Regarding Prevention of Mother to Child Transmission of HIV/AIDS among Antenatal Mothers in Nepal. JCMS Nepal. 2018;14(1):44-8.

\section{INTRODUCTION}

Prevention of Mother to child Transmission (PMTCT) is a global intervention aimed at preventing mother to child transmission of HIV. ${ }^{1}$ Around 15 to $30 \%$ of babies born to HIV (Human Immunodeficiency virus) infected women are prone to HIV infection during pregnancy and delivery in case of lack of treatment and five to $20 \%$ can also become infected through breastfeeding. ${ }^{2}$ Without treatment, one third of children living with HIV die before the age of one year and almost half by the second year. ${ }^{3}$

The risk of Mother to child Transmission (MTCT) can be reduced to below two percent by interventions that include antiretroviral prophylaxis given to women during pregnancy starting from 14 weeks of pregnancy, delivery and post-partum period and lifelong Anti-Retroviral Therapy (ARV). Likewise it also includes prophylaxis for baby started immediately after birth and continued for the first 6 weeks of life, safer delivery practice and safer infant feeding practices. ${ }^{1}$ 
At present MTCT of HIV has become a major area of concern in developing countries because it is the most common source of HIV infection in children. The HIV prevalence rate among pregnant women is estimated to be $0.2 \%$ in Nepal and among them, $90 \%$ of the reported cases are of child bearing age (15 to 49 years). ${ }^{1}$ So, it is important that the pregnant mothers should be quite aware of this situation and should have sufficient knowledge and awareness regarding this. The study purposes to find out the knowledge of pregnant women about MTCT of HIV/AIDS.

\section{MATERIALS AND METHODS}

This was a cross-sectional study undertaken at Paropakar Maternity and Women's Hospital, Thapathali, Kathmandu, Nepal. Pregnant women who came to visit Antenatal Clinic in Out Patient Department (OPD) were included in the study. Of those, only newly diagnosed pregnant women were included in the study. The sample size was 80 .

Data was collected using non-probability purposive sampling technique. A structured questionnaire was developed to assess the knowledge of antenatal mothers by doing face to face interview. Pre-testing of the questionnaire was carried out and content validity was done with expert consultation and literature review. Data analysis and interpretation were done in SPSS and MS Excel.

\section{Ethical consideration}

Ethical approval was granted by the Institutional Review Committee of Paropakar Maternity and Women's Hospital to conduct the study. Informed written as well as verbal consent was taken from the respondents before asking the questions.

\section{RESULTS}

\section{Socio-demographic information}

Table 1: Socio-demographic details

\begin{tabular}{lll} 
Variable & & Number (\%) \\
Age (years) & $15-19$ & $5(6.3 \%)$ \\
& $20-24$ & $47(58.8 \%)$ \\
& $25-29$ & $20(25 \%)$ \\
Education & $30-34$ & $8(10 \%)$ \\
& Illiterate & $8(10 \%)$ \\
& Primary level & $9(12.5 \%)$ \\
& Secondary level & $20(27.8 \%)$ \\
& Higher & $43(59.7 \%)$ \\
& Education & \\
Occupation & Housewife & $48(60 \%)$ \\
& Service & $14(18 \%)$ \\
& Student & $10(12 \%)$ \\
& Others & $8(10 \%)$ \\
\hline
\end{tabular}

In the study, the total number of respondents was 80. Among them, 47 (58.8\%) were in the age group $20-24$ years with mean age of 27.4 years. Only few $(\mathrm{n}=5,6.3 \%)$ antenatal mothers were adolescents $(15$ -19 years $)$. It was found that $90 \%(n=72)$ of the respondents were literate. Among those 72 cases, $43(59.7 \%)$ had received higher education, 20 $(27.8 \%)$ had received secondary level and 9 $(12.5 \%)$ had received primary education level. Out of total cases, majority of the respondents were housewives $(\mathrm{n}=48,60 \%)$ followed by $14(18 \%)$ service holder, $10(12 \%)$ students and $8(10 \%)$ from other occupation (Table 1).

\section{Knowledge of PMTCT among respondents}

Regarding knowledge on PMTCT, 69 (86.3\%) respondents were well aware about it. Among those 69 respondents, $58(84.4 \%)$ had knowledge of transmission of HIV during pregnancy, delivery, and breast feeding, $52(75.4 \%)$ knew about the chances of transmission of HIV from infected mother to child; among them only $7(13.5 \%)$ gave the correct answer. Interestingly, it was found that, $100 \%(n=80)$ of the respondents agreed that every pregnant woman should go through the volunteering testing of HIV/AIDS.

Looking at the knowledge regarding availability of drugs to reduce MTCT, 43 (54\%) respondents knew about the availability of drugs. Out of those 43 respondents, only $10(23.3 \%)$ said that drugs can be used during pregnancy, labour and post-partum, 6 $(13.9 \%)$ said that drugs can be used before pregnancy whereas $27(62.7 \%)$ were unknown about it.

Regarding knowledge about the place of delivery for HIV infected mothers, maximum respondents $(n=72,90 \%)$ said that HIV infected mother should go to hospital for delivery and $8(10 \%)$ answered about home delivery.

With respect to knowledge about breast feeding the baby from HIV positive mother, 48 (60\%) respondents were against breast feeding. Of the remaining $32(40 \%)$ who replied there can be breastfeeding, 7 (21.8\%) replied that HIV infected mother can do exclusive breast feeding to their babies, $3(9.4 \%)$ of them said that mixed feeding is better and 22 (70.4\%) were unknown about the type of breast feeding. The knowledge of PMTCT among respondents is summarized in Table 3.

\section{DISCUSSION}

The study found that all of the respondents had 
Table 2: Knowledge of HIV/AIDS among the respondents

\begin{tabular}{|c|c|c|c|c|c|}
\hline Knowledge & Respor & & & & \\
\hline & & Yes $(n=80,10$ & o) I knew it & hrough........ & \\
\hline $\begin{array}{l}\text { Have you heard about HIV/ } \\
\text { AIDS? }\end{array}$ & No $(n=0)$ & Radio/TV/ & Friends & $\begin{array}{l}\text { Newspaper/ } \\
\text { Books }\end{array}$ & Family/ \\
\hline & & Yes $(n=67,8$ & It is confirr & hed through....... & \\
\hline $\begin{array}{l}\text { Have you heard about } \\
\text { diagnostic test of HIV/ } \\
\text { AIDS? }\end{array}$ & $\begin{array}{l}\text { No }(n=13, \\
16 \%)\end{array}$ & Blood test & $\begin{array}{l}\text { Looking } \\
\text { face }\end{array}$ & Urine test & $\begin{array}{l}\text { Don't } \\
\text { know }\end{array}$ \\
\hline & & $63(94.1 \%)$ & $2(2.4 \%)$ & $2(2.4 \%)$ & 0 \\
\hline & & Yes $(n=26,32$ & o) It is.. & & \\
\hline $\begin{array}{l}\text { Have you heard about } \\
\text { window period? }\end{array}$ & $\begin{array}{l}\text { No }(n=54, \\
67.5 \%)\end{array}$ & $\begin{array}{l}\text { HIV present } \\
\text { in blood but } \\
\text { test is } \\
\text { negative }\end{array}$ & $\begin{array}{l}\text { HIV test } \\
\text { is positive }\end{array}$ & $\begin{array}{l}\text { Present sign and } \\
\text { symptoms of } \\
\text { AIDS }\end{array}$ & $\begin{array}{l}\text { Don't } \\
\text { know }\end{array}$ \\
\hline & & $7(26.9 \%)$ & $2(7.7 \%)$ & $5(19.2 \%)$ & $12(46.2 \%)$ \\
\hline & & Yes $(n=75$ & ) It is thr & gh........ & \\
\hline $\begin{array}{l}\text { Have you heard about } \\
\text { routes of HIV transmission? }\end{array}$ & $\begin{array}{l}\text { No } \\
(\mathrm{n}=5,6.3 \%)\end{array}$ & $\begin{array}{l}\text { Unprotected } \\
\text { sexual } \\
\text { intercourse, } \\
\text { sharing } \\
\text { needles }\end{array}$ & $\begin{array}{l}\text { Shaking } \\
\text { hands }\end{array}$ & Kissing & $\begin{array}{l}\text { Don't } \\
\text { know }\end{array}$ \\
\hline & & $75(100 \%)$ & 0 & 0 & 0 \\
\hline
\end{tabular}

knowledge about HIV/AIDS. This can be due to good education level among the respondents. The level of awareness of HIV/AIDS among antenatal mothers was found to be very high in similar other studies. ${ }^{4-7}$ Majority of the respondents mentioned that radio, TV/Media were the main source of information about HIV/AIDS which is similar to another study. ${ }^{4}$ These instruments of mass communication have been shown to be effective among literate people. ${ }^{4}$

In the study, majority were well aware about the knowledge on MTCT of HIV/AIDS. Almost all the respondents were familiar with mode of transmission of HIV/AIDS. And all of them knew that unprotected sexual intercourse and sharing needles were the commonest mode of transmission which is similar to other many studies. ${ }^{4,5,7-9}$ Low level of knowledge of MTCT was recorded in a study conducted in Uganda and Tanzania. ${ }^{10}$ Similarly, only four respondents gave correct answers regarding chances of transmission. According to another study also, specific knowledge of the respondents about routes or modes of transmission to a child is low. ${ }^{4}$

The study further showed that, only $54 \%$ respondents were aware about the availability of drugs for infected mother to reduce MTCT. However, among them $76.7 \%$ were unaware about the time when the drugs are usually given to the mother. Most of the respondents were against breast feeding during HIV infection. As UN joint commission on AIDS has recommended that the primary cause of infant death is infection and malnutrition, breast feeding should be universal. Some of the respondents had similar view suggesting that HIV woman can breast feed their child. $^{11}$

\section{CONCLUSION}

The level of awareness about PMTCT among antenatal mothers was good. However, knowledge was seen to be inadequate and thus there is need of health education about MTCT of HIV/AIDS in every health facilities of Nepal.

\section{Limitation of the study}

The study was based on a small sample size of women from a single hospital so the findings might not be generalized to the national level. 
Table 3: Knowledge of PMTCT among the respondents

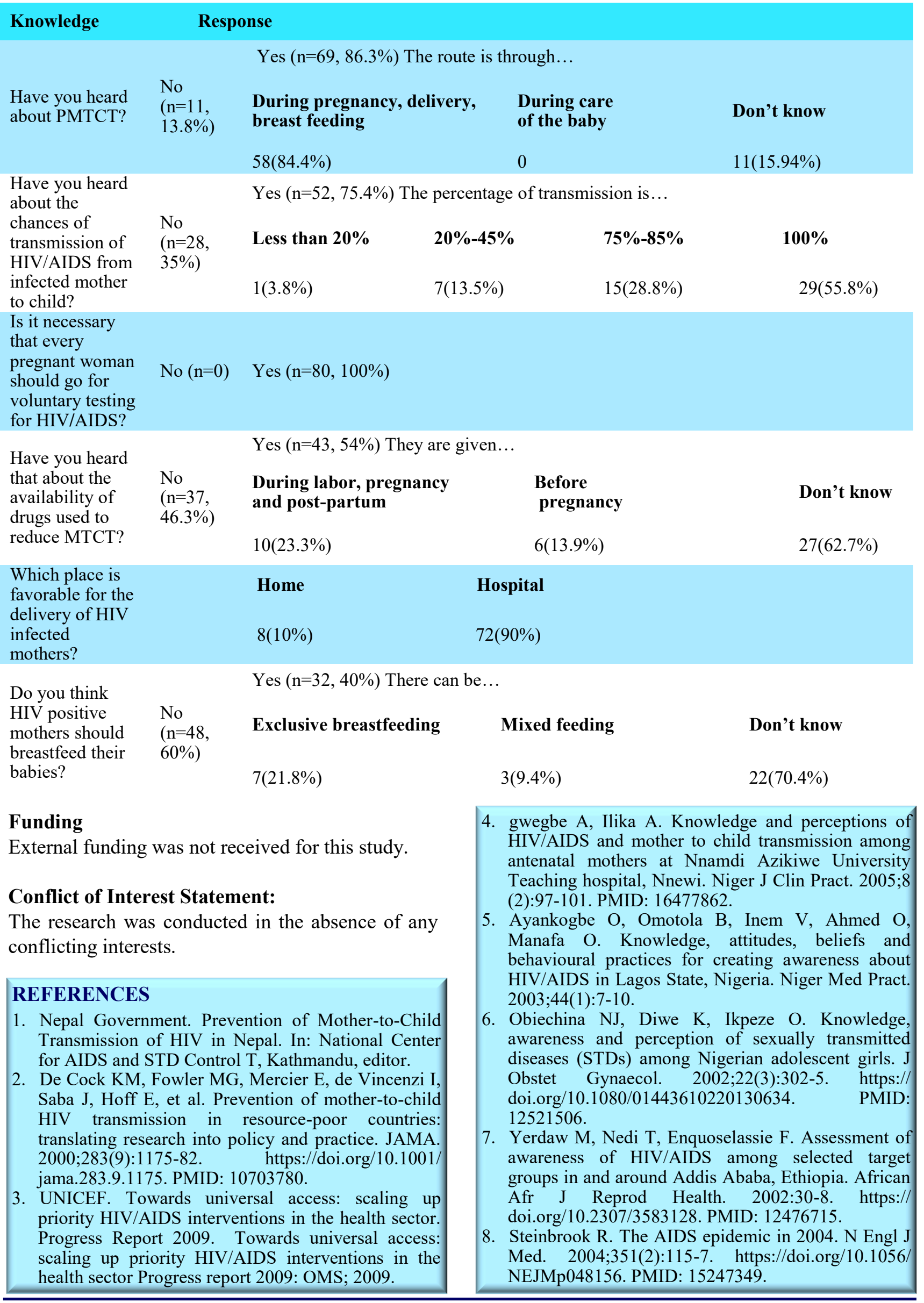


9. Fawole OI, Asuzu MC, Oduntan SO. Survey of knowledge, attitudes and sexual practices relating to HIV infection/AIDS among Nigerian secondary school students. Afr J Reprod Health. 1999:15-24. https://doi.org/10.2307/3583357.

10. Harms G, Mayer A, Karcher H. Prevention of mother to child transmission of HIV in Kenya, Tanzania and Uganda. Berlin: Report of government of Tanzania PMTCT project. International coordination office. 2003:1-26.

11. Piot P, Bartos M, Ghys PD, Walker N, Schwartländer B. The global impact of HIV/AIDS. Nature. 2001;410(6831):968-73. doi.org/10.1038/35073639. PMID: 11309626. 